\title{
Discussion on the Curriculum Reform of Electrical Automation Major in Newly Built Universities
}

\author{
Pengcheng Chen ${ }^{1, a}$ \\ ${ }^{1}$ School of Automation and Electrical Engineering, Linyi University, linyi, shandong, 276005, china \\ aemail: 765321088@qq.com
}

\begin{abstract}
Keywords: Electrical Engineering and Automation; Course Construction; Faculty; Laboratory Construction; Quality Control System
\end{abstract}

\begin{abstract}
With the development of electronic information technology, the electrical engineering and automation has been integrated into various fields of social production and routine life. The methods for cultivating electrical engineering talents with practical application ability are the hot topics that college educators should pay attention to. This paper has discussed in detail the five aspects of the construction of the electrical engineering and automation: The formation of students with good professional knowledge structure for the purpose of the development of teaching plans; Set the scientific, advanced, holistic, characteristic in a course construction; "Theory with practice, knowledge with skills" closely integrated for the "double teacher" faculty construction; On the basis of personnel training, in accordance with the principle of "high quality, high starting point and high standard", to improve the efficiency of experimental training resources for the purpose of laboratory construction; Improve the teaching management and teaching quality monitoring system.
\end{abstract}

\section{Professional Characteristics and Training Objectives}

The training objectives pf the electrical engineering and automation in the local general undergraduate colleges is to develop application-oriented engineering and technical personnel. They are characterized by: strong power-based, strong and weak combination, electrical technology and electronic technology, software and hardware combination, components and systems combined [1]. The students who are trained should have strong system concept and generous knowledge, and have strong engineering practice ability and innovation ability. Therefore, the professional training personnel goals in the electrical engineering and automation are: to cultivate the moral, intellectual, physical and aesthetic development, which aims to meet the needs of the local economic construction. These students should have a solid theoretical knowledge with a wide range of professional knowledge, practical ability, high overall quality. They are able to engage in electrical engineering-related system operation, automatic control, power electronics technology, information processing, test analysis, research and development and electronics and computer Technical applications and so on. The training program should be based on the training objectives. Attention should be paid to the integration of teaching and training as a whole, to integrate knowledge and ability training as a whole, to strengthen the overall quality of students to develop, so that students adapt to the needs of social and economic development. The important guarantee for cultivating high quality engineering construction talents is a good teaching plan.

\section{The Development of Professional Teaching Plan}

The purpose of teaching is to help students form a good professional knowledge structure, which aims to achieve the training objectives. In the development of teaching plans, the principles are as follows: to strengthen the overall quality of students training; the overall quality includes the ideological and moral quality, the ability of business ability, psychological quality, cultural accomplishment, physical fitness, etc. [2]. The four aspects of the course should include: the basis of basic courses; professional core courses; professional direction courses; professional optional 
courses. In addition to the professional knowledge, the efforts for students should meet the requirements with the humanities and social science, management science, foreign-language comprehensive ability and the cultivating moral, intellectual, physical and aesthetic development. The electrical engineering and automation discipline is a practical discipline [3]. At present, Chinese enterprises generally cannot provide the opportunity for college students to provide engineering training, so the universities provide students with the appropriate training opportunities so that students have a relatively strong practical ability. Practice includes course experiments, skills training, course design, engineering practice, graduation design, extracurricular practice and other means. This requires the students to form the complete knowledge structure: to master the electrical engineering and automation of the basic theory, basic knowledge; system to understand the latest developments in electrical automation and its development; master the typical electrical automation system components, working principle and application tools. In terms of the capacity structure: students should have certain practical ability, software programming and computer application ability; with small control system and information system analysis, design and development capabilities; strong professional learning ability and work adaptability; of the technological practical ability and the necessary basic engineering skills. In terms of capacity expertise: students should in line with the general electrical automation system analysis and design capabilities, commonly used electronic design, software application capabilities.

\section{To Develop a Scientific, Advanced, Holistic, Unique Course System}

To complete the goal of personnel training, a set of scientific, advanced, holistic, unique course system should be developed. The course is divided into five categories: excellent courses, excellent courses, key construction courses, special courses, and qualified courses. Excellent courses should be highly academic attainments, with rich experience in teaching professors, associate professor, through the construction of quality courses gradually formed a reasonable structure, stable staff, high teaching level, teaching effect of good teacher echelon, according to a certain proportion of equipment tutors and experimental teachers. The school encourages graduate students to participate in the construction of excellent courses. There is a relatively stable, structured teacher echelon. The teacher must be a professor or an associate professor, who plans to strengthen the training of young teachers. The syllabus is scientific, cutting forward, practical, and has certain characteristics. The establishment of a reasonable structure should have a clear course construction plan. Based on the characteristics of the course, a scientific, cutting-edge, practical teaching syllabus, teaching method is developed. The modern educational technology is used actively. Teachers with rich teaching and practical experience are encouraged to prepare teaching materials or handouts with local characteristics, and cultivate special talents for local economic development.

\section{The Construction of a "Double-teacher" Team with Practical and Teaching Abilities}

The school education should be teacher-oriented. As a professional teacher of electrical information, he or she should be the theory and practice, knowledge and skills closely integrated teacher. Most of the teachers in universities and colleges are from the university. They are directly sent to the university but they lack the practical experience. It is unrealistic to train them to develop high-quality applied talents. Teachers usually have the heavy teaching tasks. The summer vacation or special semester arrangements for teachers are used for the factory dress training, participation in enterprise technology development, as the enterprises' technical resources. In addition, the school should encourage teachers to actively declare scientific research projects, participate in production and research engineering technology projects as soon as possible. After several years of training, the ability of "double-teacher” will be obtained[4]. 


\section{Improve the Efficiency of Experimental Training Resources and Strengthen the Laboratory Construction with Practical Teaching}

Change the concept, raise awareness, strengthen the professional practice of teaching the status of professional teachers and students to achieve "practice is the fundamental engineering" consensus. Firmly establish the "practical teaching with the theory of teaching equal importance", "practice is the success of engineering talent" of the educational philosophy. Through the course system and the reform of educational content, the theory of teaching and practice teaching can be equal.

The establishment of the school training center aims to consolidate and expand the training base outside the school through the integration of resources, school investment, the construction of open, for the actual post, well-equipped, advanced functional training center. Improve the efficiency of experimental training resources. Students can follow their own expertise and interest to the training center to operate and skills training, allowing students to engage in scientific and technological experiments, technological innovation and other creative activities. The training base in the school has the advantage of being timely, convenient and effective in practice teaching. In view of the current establishment of the school internship factory conditions are not mature, the school training mainly in the professional laboratory (training center). Extracurricular practice teaching is authentic and practical. Through the school-enterprise cooperation, in the community to select some enterprises, the company established a relatively stable training base. While strengthening the job skills training, at the same time, the number of technological innovation, product design, program demonstration, management training, high-tech operations etc. are increased.

A solid training base inside and outside the school should be established to explore the "internal skills, external technology" practice teaching mode Students basic operating skills, initial professional skills from the training base to solve the school training. On this basis, schools encourage students to participate in the technical professional practice. A solid off-campus training base should be established on the basis of in-depth research to understand the employer's production, job placement, talent needs and business development planning and other conditions. In the last semester, according to the students personal expertise, to take commission internship, internship, employment practice and other forms of graduates to enter the employer.

Practice teaching and practice teaching should follow the training rules of skills and ability training, in accordance with the system, level and step by step teaching principles, to build from the basic skills, special ability, comprehensive ability and application ability multi-stage training and theory Teaching system of organic integration and independent of the practice of teaching system [1]. According to the professional positioning and training objectives, in the development of teaching plans, the theory of compression will increase the experimental teaching hours, and improve the content of practical teaching. The course experiment is enriched and transformed to reduce the verification experiment and increase the application of a number of comprehensive and design experiments. In the way of teaching lectures, the script, unified experimental methods and steps is avoided. For example, electrical engineering experiments in the active two-terminal network equivalent parameters of the measurement methods are: open circuit voltage, short circuit current method; voltammetry; half voltage method; zero show method. In the past, students rely entirely on teachers. Personality cannot be developed. If the students can choose according to the principles and equipment conditions, the concern about which method is simple, more reasonable, small error etc. should be taken. The effect of teaching is clearly not the same. In the integrated design of experimental teaching, teachers provide some small design topics, mainly by the students to complete their own. In the face of problems, teachers and students will solve the problems. In addition, students can also be based on personal interests and hobbies, in the completion of the project will be done, after the basic training, combined with their own situation to participate in difficult to participate in the experimental project topics. In this way, the student's dominant position and the dominant position of the teacher can be reflected, so as to stimulate students to explore the desire of knowledge, training students study the habit of learning. In addition, actively 
open up the second class, cultivate the practical ability of college students. First, the organization of students to actively declare the establishment of the college "university research fund" project. Through the development of student research activities, students experienced the whole process of self-learning, but also simulated the project application, production, the whole process of the title, the ability to develop is all-round. Second, relying on the electronic association of college students to open up the application of electronic design ability of college students. Third, to carry out various competitions, team to participate in provincial and national competitions and to point to carry out all-round practice training.

\section{Conclusions}

The teaching management and teaching quality monitoring system are reflected in the following:

(1) To improve the teaching management rules and regulations, so that teaching management into a standardized, institutional and scientific track. The teaching contents should meet the knowledge structure and skill requirements that the society needs, the actual situation of the students, the practical teaching management rules and regulations, such as the main teaching "quality standards", "the main part of the practice of teaching quality standards", "leadership and teacher lectures", "teacher preparation system", "student examination management system", "examination marking and performance assessment norms", "evaluation system” etc.

(2) To implement the teaching plan, and constantly strengthen the teaching operation of the monitoring work, and strive to implement the rules and regulations and relevant provisions.

(3) To implement the daily teaching of the two-way attendance system, and adhere to the leadership system, teaching information staff feedback system and teacher classroom teaching evaluation system, to understand the teaching situation, improve teaching methods, improve teaching quality.

(4) To establish the entire teaching and inspection system. At the beginning of the semester to check the preparation of teaching, mid-term to meet the school during the self-examination, the end of the examination, pay close attention to test the wind to promote style of study. To further strengthen the examination management, take the form of centralized marking, water operations.

(5) To implement the tutor system. The implementation of the tutor system has played a certain role in accelerating the growth of young teachers.

(6) To carry out various forms of teaching and research activities. The lectures, open classes, demonstration classes, teaching reform courses, teaching topics, difficult consultation etc. are included. The development of these activities has played a positive role in improving the quality of teaching.

(7) To strengthen the management of practical teaching links. Experimental teaching syllabus, experimental instruction book, experimental results register and other materials require specification, complete, reasonable teaching arrangements, the implementation of good condition.

(8) To manage various teaching materials in line with the norms. Each semester teachers to submit the teaching files (including student papers, test paper analysis, results, experimental reports, teacher lectures, etc.) require complete specifications.

We will continue to explore and research in accordance with the professional development requirements in the electrical engineering and automation, which aims to cultivate the high-quality applied talents with the innovative ability as required by the times.

\section{References}

[1] Song W H. Deficiencies and Countermeasures on the Education of Pre-service Foreign Language Teachers in Higher Normal Colleges and Universities in the New Curriculum Reform[J]. Educational Research on Foreign Languages \& Arts, 2011.

[2] Ding X, Huang Y X. Discover and practice on teachers professional training mode in the context of new curriculum reform[J]. Journal of Hubei Normal University, 2010. 
[3] Tang H M. The Practice Teaching Reform of Normal Colleges Under the Background of a New Curriculum[J]. Journal of Huzhou Teachers College, 2011.

[4] Huang S J. The Research on the Measures and Problem of the Implementation of Textbook under the Reform of New Curriculum[J]. Education \& Teaching Research, 2009

[5] Yang-Yang L I, Wang X C. Investigation on P.E. Teachers' Identities of Profession Competence under the Background of New Curriculum Reform in Middle Schools[J]. Journal of Shenyang Sport University, 2007. 